\title{
Phage-Phagocyte Interactions and Their Implications for Phage Application as Therapeutics
}

\author{
Ewa Jończyk-Matysiak 1,*, Beata Weber-Dąbrowska 1,2 , Barbara Owczarek ${ }^{1}$, \\ Ryszard Międzybrodzki ${ }^{1,2,3}$, Marzanna Lusiak-Szelachowska ${ }^{1}$, Norbert Lodej ${ }^{1}$ and \\ Andrzej Górski 1,2,3 \\ 1 Bacteriophage Laboratory, Ludwik Hirszfeld Institute of Immunology and Experimental Therapy, \\ Polish Academy of Sciences, Rudolfa Weigla Street 12, 53-114 Wroclaw, Poland; \\ weber@iitd.pan.wroc.pl (B.W.-D.); owczarek@iitd.pan.wroc.pl (B.O.); mbrodzki@iitd.pan.wroc.pl (R.M.); \\ marzena@iitd.pan.wroc.pl (M.Ł-.S.); norbert.lodej@iitd.pan.wroc.pl (N.Ł.); agorski@ikp.pl (A.G.) \\ 2 Phage Therapy Unit, Ludwik Hirszfeld Institute of Immunology and Experimental Therapy, \\ Polish Academy of Sciences, Rudolfa Weigla Street 12, 53-114 Wroclaw, Poland \\ 3 Department of Clinical Immunology, Transplantation Institute, Medical University of Warsaw, \\ Nowogrodzka Street 59, 02-006 Warsaw, Poland \\ * Correspondence: ewa.jonczyk@iitd.pan.wroc.pl; Tel.: +48-71-337-11-72
}

Academic Editor: Tessa Quax

Received: 31 March 2017; Accepted: 7 June 2017; Published: 14 June 2017

\begin{abstract}
Phagocytes are the main component of innate immunity. They remove pathogens and particles from organisms using their bactericidal tools in the form of both reactive oxygen species and degrading enzymes-contained in granules-that are potentially toxic proteins. Therefore, it is important to investigate the possible interactions between phages and immune cells and avoid any phage side effects on them. Recent progress in knowledge concerning the influence of phages on phagocytes is also important as such interactions may shape the immune response. In this review we have summarized the current knowledge on phage interactions with phagocytes described so far and their potential implications for phage therapy. The data suggesting that phage do not downregulate important phagocyte functions are especially relevant for the concept of phage therapy.
\end{abstract}

Keywords: phagocytes; phages; intracellular killing of bacteria; phagocytosis; monocytes; granulocytes; dendritic cells

\section{Introduction}

Phagocytes are the main component of human innate immunity. In the human body phagocytic cells are neutrophils, monocytes, tissue macrophages and dendritic cells [1]. Their function is based on the non-specific defense of the body against pathogens and substances produced by them, e.g., toxins, which involves uptake of the antigen and its degradation in the phagosome, where degrading enzymes are present [2,3]. After the pathogens' entry into the body the number of circulating leukocytes increases. Leukocytosis is observed in the course of infection or inflammation [4].

Mature neutrophils are short-lived cells, but they circulate in a huge amount (their production is about $10^{9}$ cells $/ \mathrm{kg} /$ day; they represent $50-70 \%$ of all leukocytes in an adult's peripheral blood $[4,5]$. They digest extracellular pathogens and their toxins. Neutrophils achieve high effectiveness in killing bacteria by combining the action of reactive oxygen species (ROS) and substances contained in the granules of these cells [6].

Monocytes from the bone marrow enter the peripheral blood, where they circulate for 2-3 days [7], before passing into the tissues and converting into macrophages-present in the connective tissue (histiocytes), liver (Kupffer cells), spleen, lungs (alveolar macrophages) and central nervous system 
(microglial cells) [8]. The percentage of monocytes does not exceed 10\% of the total number of white blood cells. Their role is based on removing potentially harmful particles, e.g., microorganisms, dead cells, or their residues, processing them and presenting antigens to lymphocytes [1]. This is one of many mechanisms linking the innate to adaptive immunity. Monocytes also regulate the function of antigen presenting cells, e.g., dendritic cells. The main tasks of macrophages include removal of pathogens or particles potentially harmful in the process of phagocytosis, antigen presentation to $\mathrm{T}$ cells, and the production of cytokines [8]. Splenic macrophages are important especially in the removal of capsular bacteria (e.g., Neisseria meningitidis). Macrophages have a weaker respiratory burst, and their mature forms neither show the presence of myeloperoxidase nor include numerous antimicrobial proteins. The cytoplasm of macrophages does not possess granules with NADPH oxidase, which is compensated by the induction of cytokine production. Together, bacteria, their products, inflammatory cytokines, and interferon stimulate NO synthase, which is the main path of bactericidal activity of macrophages [9].

Dendritic cells (DC) derive from myeloid progenitor cells in the bone marrow, and they colonize tissues. One of these cell subtypes-myeloid dendritic cells-is functionally and developmentally related to macrophages. They have a common precursor with macrophages, and may also transform into macrophages [10]. Immature forms of dendritic cells are able to undergo phagocytosis, whereas upon activation they migrate to the lymph nodes, where the cells present antigens to T lymphocytes.

Phagocytosis leads to the destruction of pathogens penetrating the body [4]. It occurs as a result of direct or indirect (e.g., due to opsonization) identification of microorganisms [11]. The process consists of: targeted traffic of phagocytes (chemotaxis) toward the source of infection; recognition of foreign particles by membrane receptors located on the surface of phagocyte e.g., lectins; absorption of the particles into the vacuole (phagosome); degranulation and release of intracellular granules' enzymes into the phagosome (phagolysosome formation); the production of ROS by the enzyme complex which is located in the cell membrane and/or reactive forms of nitrogen; and killing and digesting the material in the phagosome.

Bacteriophages are the most numerous structures in the biosphere [12-14]. Because they are so abundant, they constantly interact with organisms, and not only with bacteria that they infect. They are present in the human microbiome, and therefore they are well tolerated when used in phage therapy [15,16]. It has been proved that they can adhere to the eukaryotic cells [17]. Moreover, phage therapy increases the exposure of human (the patient's) cells to these prokaryotic viruses, and it may exert an effect especially on immune cells. Nowadays, phages are seen as innovative components as a hope in fighting the antibiotic resistance [18], and this form of therapy is becoming increasingly popular and more frequently used because of antibiotics' crisis [19]. Therefore, it is extremely significant from the safety point of view to determine if phages do not impair the functions of phagocytes, even if they are applied in immunocompromised patients, who constitute a significant proportion of patients who qualify for experimental phage therapy [20].

Eight years ago, in their paper, Kurzepa et al. (2009) stated that "the present knowledge about phage interactions with cellular components of the mammalian immune system is sparse and insufficient, especially considering the increasing interest in the application of these viruses in human life. We believe that continuation of such research is indispensable" [21]. In subsequent years new and important data have accumulated which shed more light on phage-phagocyte interactions.

\section{Phagocytosis of Bacteriophages}

The process of bacteriophage phagocytosis by phagocytic cells has been described. Although phages are bacterial viruses, interactions between them and human or animal immune cells have been observed.

As demonstrated by Aronov et al. (1964), bacteriophages can be ingested by phagocytic cells during phagocytosis [22]. Phagocytosis of the Escherichia coli T2 bacteriophage by macrophages and rabbit peritoneal neutrophils as well as disintegration of phage virions in vitro was described. 
The inactivation of phages localized within macrophages was observed $2 \mathrm{~h}$ after phagocytosis. Phages are capable of attaching to the cell membrane of leukocytes [23]. It was suggested that also phage vectors enter mammalian cells by endocytosis mediated by integrins. Following their entry into cells in the phagocytosis-like process, the vectors initially retained their lytic activity [24]. Then, they were transported to lysosomes, where the phages were inactivated in the acidic environment in the presence of $100 \mu \mathrm{M}$ of chloroquine.

Barfoot et al. (1989) observed phagocytosis of the T4 phage by dendritic cells in vitro [25]. This process was more effective in the case of the T4 phage and the influenza virus particles than the synthetic particles (latex). Active virions were more effectively phagocytosed. What is more, phages were localized in phagolysosomes. During phagocytosis the phage's outer coat was removed. Recently, Kazmierczak et al. (2014) obtained T4 phage particles (containing the fusion protein GFP + Hoc) showing green fluorescence [26]. By incubating them with the murine macrophage cell line J774A.1 green fluorescence was observed within macrophages. These observations confirmed that these cells have the ability to phagocytose the T4 phage. Also Hodyra-Stefaniak et al. (2015) visualized phage degradation by splenocytes and identified the phage particle within macrophage compartments (using super-resolution structural-illumination microscopy and green fluorescent protein-labeled phage) [27]. The results can contribute to further innovative development and use of phages for phage therapy, e.g., for the treatment of infections caused by intracellular bacteria or monitoring the location of the phages in living organisms or tissues. These above findings confirm that phages may interact with phagocytic cells as well as penetrate them. Phage particles' degradation within phagocytes may be observed, and may be one of the reasons for phage insusceptibility. However, whether particular phage particles would be degraded may be a phage's individual feature and may determine the fate of the treatment using phage therapy.

\section{Phage Influence on Phagocytosis of Bacteria}

An interesting area seems to be research concerning whether phages may influence phagocytosis of bacteria. The first observations on the interactions of phages and immune cells were made in vivo and in vitro in the 1920s [28]. D 'Herelle studied the effect of phages active against Shigella on phagocytosis of bacteria by guinea pig leukocytes. He observed that the index of phagocytosis of Shigella grew after $10 \mathrm{~min}$ ' incubation of bacteria, phages and leukocytes, compared to controls, in which the cells were incubated only with the bacteria in the absence of phage. This study revealed that bacteria that have acquired resistance to these specific phages also become resistant to phagocytosis. It suggested that this phenomenon could be explained by the fact that phages act as opsonins that facilitate phagocytosis of bacteria. Similarly, Nelson (1928) demonstrated in vivo that phagocytosis is a process which may be affected by phages active against Staphylococcus aureus [29]. Intravenous administration of phages resulted in an immediate increase in the ability of leukocytes to phagocytose bacteria susceptible to phage. But in the case of phage-resistant bacteria the strength of phagocytosis remained unchanged.

However, Młynarczyk et al. (1988) reported that lysogenic conversion may have an influence on the susceptibility of S. aureus to phagocytosis [30]. Intracellular killing (IK) of the lysogenic 8325-4 strain of $S$. aureus by granulocytes was weaker compared to the strain without integrated prophage. These results could be related to the fact that genes of some prophages may have an influence on the synthesis of the antiphagocytic surface receptors or may result from the presence of $R$ plasmids in the S. aureus cells. Similarly, Secor et al. (2017) demonstrated that bone marrow dendritic cells internalized the Pseudomonas aeruginosa strain with integrated phage less than the bacterial strain itself. The bacterial strain producing the filamentous Pf4 phage was observed to be less susceptible to phagocytosis by macrophages than those not producing the Pf phage [31]. This is contradictory to Smith's (1928) observations, which suggested that exposure of live bacteria to specific phage increases susceptibility to bacterial phagocytosis [32].

The effect of phage therapy on S. aureus phagocytosis by neutrophils of patients who were treated with phages was investigated [33]. The decrease in bactericidal activity of the phagocytes was observed 
in the case of patients whose phagocytes had shown impairment in phagocytosis already prior to the therapy. However, there was no correlation between changes in phagocytosis and the course of therapy. Interestingly, three months after the treatment with phages neutrophils of these patients started to gradually recover their capacity for phagocytosis. However, during the first weeks of phage therapy increased phagocytosis by neutrophils was observed in patients in whom the therapy gave good results, which would indicate that assessing phagocytosis may have a prognostic value in phage therapy [20].

Data presented herein show that there is no universal type of phage influence on phagocytosis either in vitro or in vivo. The observed effects may depend on, e.g., the type of phage, bacteria as well as type of phagocytes.

\section{Phage Influence on Intracellular Killing of Bacteria}

Intracellular killing of bacteria was shown to be influenced by phages. This process is fundamental for pathogens' elimination by innate immunity. It was demonstrated that peripheral blood phagocytes' (both polymorphonuclear leukocytes (PMNs) and peripheral blood mononuclear cells (PBMCs)) ability to kill bacteria (pathogenic and nonpathogenic) intracellularly, in patients suffering chronic infections who were qualified for experimental phage therapy, was impaired [34] More importantly, it was also found that phage therapy did not cause a further decrease in patients' phagocytes' ability to kill bacteria (both the pathogenic and the reference bacteria). What is more, in patients with urinary tract infections phage treatment corrected the weakened IK of nonpathogenic bacteria by monocytes. The results confirm the data derived from the studies conducted by Kurzepa-Skaradzińska et al. (2013) in vitro [35]. The authors reported that the phage preparations (both in lysate and purified form) did not affect the capacity of human phagocytes for IK of bacteria, regardless of the titer of the phage preparation and its specificity for the bacterial strain (homologous and heterologous). Moreover, our unpublished data obtained from mice with an experimentally induced urinary tract infection also indicated that the bacterial infection reduced the bactericidal capacity of phagocytes isolated from mouse spleen, regardless of the uropathogenic strain used to induce the acute urinary tract infection (Enterococcus faecalis or P. aeruginosa). The use of three consecutive doses of phage lysate after induction of the acute infection exerted a stimulatory effect on intracellular killing of bacteria by mouse splenocytes. This process was normalized to the level observed in the control group (phagocytes of healthy animals) 6 days after the infection induction. Our results confirm that phage therapy has no harmful effects on the bactericidal properties of peripheral blood phagocytes of patients treated with phage lysates.

The reduced ability of whole blood to kill methicillin-resistant $S$. aureus intracellularly was observed in BALB/c mice with experimentally induced diabetes compared to the bactericidal properties of blood of healthy animals (correlated with the glucose level in the blood) [36]. The combined use of linezolid and MR-10 phage active against $S$. aureus increased the bactericidal activity of mouse whole blood to kill bacteria intracellularly. What is more, our unpublished data (Jończyk-Matysiak et al.) also demonstrated that preincubation of the purified T4 phage with human peripheral blood phagocytes-PMNs or mononuclear cells-significantly increased the percentage of killed bacteria in vitro, compared to bacteria incubated only with the phagocytes. Similar effect of the PA1Ø phage (active against P. aeruginosa) and mouse neutrophils isolated from peripheral blood was observed against $P$. aeruginosa in vitro [37]. In the samples which contained both the phage and neutrophils, there was a significant decrease in bacterial titer, compared to samples containing the phage only, which suggested that the phage-neutrophil co-work may be essential for the efficient killing of bacteria in the mice. These findings indicate that phages may act synergistically with phagocytes in eliminating bacteria. 


\section{Phage Participation in the Killing of Intracellular Bacteria}

Pathogens avoiding phagocytosis are a major clinical problem as they can remain alive inside the phagocytes [38]. The treatment of such infections may be inefficient because many antibiotics of proven efficacy in vitro against intracellular pathogens have little or no activity in vivo. In consequence, antibiotics are used in too low concentrations to be able to destroy pathogens or stimulate the phagocytes to carry out intracellular killing of these bacteria. Moreover, not all antibiotics of proven capacity to penetrate into the interior of phagocytes can destroy bacteria. Therefore, using phages that can penetrate phagocytes is an interesting and promising option.

According to Broxmeyer et al. (2002), lytic TM4 mycobacteriophage did not show the ability of intracellular lysis of mycobacteria, because it could not penetrate to the interior of macrophages [39]. Only phages supplied to a macrophage using a non-pathogenic strain of Mycobacterium smegmatis destroyed intracellular bacteria. While testing the effect of D29 mycobacteriophage on intracellular bacteria in vitro, the authors observed that the phage was able to kill the intracellular bacteria because it had penetrated inside the macrophages. Most likely, the difference in phages' ability to penetrate to the interior of the tested phagocytes resulted from the difference in the phages' structure; probably the TM4 phage had no molecules to enable it to adsorb to the macrophage membrane and penetrate to its interior.

Interestingly, Capparelli et al. (2007) observed that phage $\mathrm{M}^{\mathrm{Sa}}$ active against S. aureus (including methicillin-resistant $S$. aureus) destroyed bacteria inside murine macrophages both in vitro and in vivo [40]. The phage alone could not penetrate into the interior of murine macrophages, whereas when supplied to the interior of the cells using S. aureus (after pre-incubation of the phage with S. aureus A170S strain), it efficiently killed bacteria that were localized intracellularly (approximately 70\%). Interestingly, the MR-5 phage specific to $S$. aureus (which was adsorbed to engulfed bacterial cells), penetrated into murine peritoneal macrophages and caused a significant reduction in titer (a decrease of $2.5 \log$ in $2 \mathrm{~h}$ ) of $S$. aureus that was localized intracellularly [41]. Phage particles which were transferred to the inside of macrophages also significantly reduced the damage caused due to cytotoxic effects of bacteria on phagocytes. What is more, the killing was higher at a lower bacteriophage/bacteria ratio, and these findings correspond with observations of Baughn and Bonventre (1975), who reported that killing of $S$. aureus by mouse peritoneal macrophages was also higher when a lower multiplicity of infection (MOI) was used in the experiments [42].

These results could suggest a potential use of phages to treat such dangerous infections as those both local and systemic caused by intracellular pathogens.

\section{Phages and Respiratory Burst}

ROS are a strong "weapon" used by phagocytic cells to eliminate pathogens absorbed by phagocytosis. There are data concerning the effect of phages on the production of ROS which are produced by phagocytes after uptake of antigen [43-45]. The purified T4 phage only weakly induced the respiratory burst in monocytes and neutrophils, as compared to bacteria [43]. However, the inhibited production of ROS by neutrophils stimulated by bacterial antigens, such as lipopolysaccharide (LPS), it was observed, either when phages specific or non-specific to bacteria were used [43]. The ability of the T4 phage and its proteins to generate ROS in neutrophils and mononuclear cells from human blood was also tested, and these results pointed to a lack of proinflammatory action of both phage and their highly purified head proteins exposed on the phage surface: the major capsid protein (gp23), gp24, highly immunogenic outer capsid protein (Hoc), and small outer capsid protein (Soc) [45]. Similarly, Borysowski et al. did not show in vitro that both purified preparations and A3/r phage lysates (active against $S$. aureus) induced the respiratory burst in either neutrophils or monocytes [46].

The above findings are contradictory but most of them showed that phages do not stimulate ROS production and as a consequence they do not contribute to damage and destruction of uninfected tissues. The use of phage preparations for systemic infections (e.g., sepsis, during which the production 
of ROS may result in damage to tissues and organs) could reduce the harmful effects of degradation products of bacteria on tissues and organs of patients.

\section{Phage Influence on the Other Steps of Phagocytosis}

Despite phage ability to influence the uptake of bacteria and/or their killing intarcellularly with the use of ROS, there are data showing that phages may interact with phagocytes at different steps of phagocytosis, e.g., their recruitment or release of substances with bactericidal activity.

Secor et al. (2017) reported that the filamentous Pf4 bacteriophage active against Pseudomonas aeruginosa in vivo (murine pneumonia model) reduced both neutrophil recruitment and the production of cytokines [31]. The authors hypothesized about both the role of the phage in the development of chronic infection and evasion of the defense mechanism of the host. They stated that the production of the filamentous phage may cause a reduction in the dissemination and inflammation caused by increased adhesion of bacterial cells to the mucin. Moreover, the production of the Pf4 phage was probably associated with macrophage polarization, and phage-associated bacteria caused the expression of higher levels of M1 and M2 markers compared to the bacterial strain itself.

Also, the effects of the A3/R purified phage and its lysate on degranulation of neutrophils' primary and secondary vesicles was tested [47]. Blood samples were investigated by flow cytometry and the expression of markers of exocytosis-CD63 (primary granules) and CD66b (secondary granules)—was investigated. The researchers found that neither the A3R purified preparation nor the phage lysate did not induce degranulation in neutrophils. This result suggest that phage therapy should not induce significant phagocyte degranulation therefore confirming its safety and low incidence of side effects.

\section{Phages and Inflammation}

We have noted a marked anti-inflammatory effect of therapy in patients receiving phage treatment; in some of them the response was dramatic even though bacterial eradication had not been achieved. This suggested that phage can mediate their anti-inflammatory action by at least two mechanisms: eradicating bacterial infection and directly downregulating the activity of cells engaged in proinflammatory processes [48].

It was demonstrated that both the T4 bacteriophage and its head proteins: gp23, gp24, Hoc, and Soc did not stimulate the inflammatory mediators and inflammation-mediated factors, particularly pro-inflammatory cytokines [45]. The authors tested the cytokine profile both in vivo (mouse model, intraperitoneal injection) and in vitro (on cells isolated from human blood). When mouse bone marrow-derived dendritic cells were treated with the T4 phage and its capsid proteins, no significant production of cytokines such as IL- $1 \alpha$, IL-6, IL-12 and TNF- $\alpha$ was observed. Moreover, the authors investigated the effect of the T4 phage and its head proteins on the differentiation and activation of bone marrow-derived dendritic cells. They observed no changes in the expression profile of cell surface antigens, such as major histocompatibility complex (MHC) class II, CD40, CD86 and CD80. The obtained data support the safety of phage preparations' application in medicine.

The effect of the T4 and A3/R purified phages and their lysates on differentiation of human myeloid dendritic cells has been investigated to some degree [49]. Neither of the tested phages influenced the expression of the markers responsible for maturation of $\mathrm{DC}$ and activation of $\mathrm{T}$ cells, such as CD40, CD80, CD83, CD86, CD1c, CD11c, MHC class II, PD-L1, PD-L2, TLR2, TLR4, and CCR7. It was also found that the phages did not influence the percentage of CD64 and DEC205 positive cells, which are known to be involved in phagocytosis. However, the T4 lysate significantly reduced the percentage of the CD64 and DEC205 positive cells, while the lysate significantly increased the percentage of the TLR4 and PDL-2 positive cells (in comparison with the control). Whereas, according to Górski et al. (2012) the T4 phage did not affect the percentage of TLR2 and TLR4 ${ }^{++}$cells, as was observed in in vitro experiments in both monocytes stimulated and those not stimulated by LPS [20]. Also in myeloid DC, which were differentiated with the addition of the A3/R lysate, the presence of DEC205 was reduced [49]. It was observed that the level of IL-12 produced by the myeloid DC in 
the presence of the $\mathrm{T} 4$ and $\mathrm{A} 3 / \mathrm{R}$ phages was undetectable, which may confirm that phages do not have an influence on the activation of $\mathrm{mDC}$. The authors suggested that the observed changes in DC marker expression may be caused by the components of bacterial cells contained in phage lysate. Also, Bocian et al. (2016) found that both the T4 purified preparation and its lysate significantly increased the percentage of monocytes with an activated phenotype $\left(\mathrm{CD} 14^{+} \mathrm{CD} 16^{-} \mathrm{CD} 40^{+}\right.$and $\left.\mathrm{CD} 14^{+} \mathrm{CD} 16^{-} \mathrm{CD} 80^{+}\right)$ in unactivated PBMCs while it had no effect on LPS-activated monocytes [50]. The authors stated that their observation may be important because it suggests that in patients infected with Gram-negative bacteria neither of the phage preparations applied in the therapy-purified phage or products of bacterial lysis in lysate form-stimulated monocytes. Ann et al. (2014) reported that the ES2 Cronobacter sakazakii phage activated dendritic cell maturation and caused an increase in the expression IL-12-p40 [51]. These findings may indicate that this phage can induce an inflammatory response.

Miernikiewicz et al. (2016) also showed that the short tail fiber protein (gp12) from the T4 phage, which mediates adsorption of the phage to E. coli, may bind and form complexes with LPS-one of the known pathogen-associated molecular patterns (PAMP) recognized by toll-like receptors [52]. The authors suggested that the phage protein may be a modulator of LPS-induced inflammation, because their results indicated that LPS in combination with gp12 did not cause any negative influence on mammalian cell proliferation (fibroblasts, endothelium), and it caused a decrease in the inflammatory response to LPS in a murine model (a reduction of the level of IL-1 $\alpha$ and Il- 6 in LPS-challenged mice). What is more, the gp12 protein itself had no proinflammatory activity in mice. The application of the protein to mice with inflammation induced by LPS caused a significant decrease in the infiltration of leukocytes into the liver and spleen. Also, no cytotoxic effect on the growth and viability of tested cell lines, either animal (murine fibroblasts, Balb3T3) or human (HSkMEC), was observed when the gp12 protein was applied, nor were there any harmful effects on tissues of mice treated only with the protein. What is more, the authors suggested the possibility to use the tested protein as a potential anti-inflammatory drug.

The response to Pseudomonas F8 and T4 phages has been described based on the mouse model [27]. The authors found that in animals with induced systemic inflammatory response syndrome (SIR) with LPS the concentration of phages in the spleen was significantly lower $(2.58 \mathrm{log})$ than in the case of the control group, which the authors associated with the decrease in phage particles circulating in the blood of mice with inflammation 1 hour after phage administration. The obtained results may be explained by the fact that spleen phagocytes isolated from SIR mice could phagocytose phages more effectively compared to control mice.

A promising perspective would be an idea of using the combined action of phages and monocytes and their properties Bacteriophages are characterized by a total negative electric charge on the surface (the negative zeta potential of -30 to $-10 \mathrm{mV}$ ) [53-57]. Such a physical property could provide a basis for using the modified phage particles to bind to the so-called inflammatory monocytes expressing chemokine receptor type 2, CCR2, which is responsible for the recruitment of these cells to sites of inflammation. The incorporation of phage particles to monocytes (by positively charged scavenger receptors on the surface of these cells) could direct these cells to the spleen, where they are subjected to apoptosis, as was observed in the case of using negatively charged biodegradable microparticles [58]. This could be a breakthrough in the treatment of pathologies caused by the so-called inflammatory monocytes.

The presented ability of phages tested so far not to participate in the development of inflammation as well as their suggested anti-inflammatory action may allow them to be an important tool for application in the treatment of infections and inflammation.

\section{Indirect Interaction with Immune Cells}

The effect of phages' interactions with the immune cells may be indirect, e.g., by the components of phage lysate that contains bacterial residues. Phage lysates may modulate the immune system. Zimecki et al. (2003) demonstrated that purified preparations of A20/R phage active against 
S. aureus have a costimulatory effect on murine splenocytes activated by suboptimal concentration of concanavalin A [59]. The results indicate that the therapeutic effect of phage preparations may be related not only to the phage bactericidal activity, but also to the stimulation of the cells of the immune system (e.g., cytokine production) and increased ability to proliferate under the action of mitogens. Stapels et al. (2014) suggested that $S$. aureus strains have the ability to synthesize serine proteinase inhibitors, which could be important in the inhibition of inflammation [60]. This could suggest a potential mechanism for the anti-inflammatory effect of staphylococcal phage lysates. Strengthening immunity can be an effect of the products presented in the phage preparations, e.g., in staphylococcal phage lysates [20].

As suggested by Górski et al. (2012), the therapeutic effect of phage preparations may be connected not only with the elimination of bacteria, but may also depend on the normalization of inflammatory markers associated with bacterial infection [20]. A decrease in C-reactive protein (CRP) levels was observed in patients treated with phage therapy [61]. Phage therapy (phage lysates) did not show proinflammatory action in patients [17]. An increase of leukocytosis and erythrocyte sedimentation rate (ESR) was not observed. Moreover, phage therapy accelerated the circulation of neutrophils, which confirmed a significant increase in the level of immature forms of neutrophils in the blood with a simultaneous decrease in mature cells [33]. However, our previous observations conducted on patients $(n=51)$ treated with phage therapy showed that the therapy does not appear to have a significant impact on the percentage of the different fractions of circulating blood leukocytes, so it probably does not affect the granulopoiesis or myelopoiesis [62]. What is more, there was no significant influence of phage therapy on inflammatory markers, either ESR or CRP, in patients who received phage therapy, and -at least in some patients-phage therapy may cause lowering of those markers which may suggest that experimental phage therapy does not stimulate the inflammation process. The results may be of practical importance as they confirm the safe use of phage lysates in patients treated with phage therapy, especially in patients with congenital and acquired immune deficiencies.

\section{Practical Implications of Phage-Phagocyte Interactions}

Pathogenic viruses' interactions with cells of the immune system include binding of virions to cells, phagocytosis and associated mechanisms (e.g., the production of ROS) and apoptosis. There exists no uniform response of the phagocytic cells to a pathogenic virus. Viral infection results in the synthesis of interferon, and its release to surrounding tissue leading to the appearance of virus-specific receptors on the surface of adjacent not-yet-infected host cells [63]. Viral particles can be degraded by neutrophil-associated proteins (contained in the granules), such as defensins, cationic proteins, and reactive oxygen species [64-66]. Activation of phagocytes caused by a viral infection is associated with the production of reactive oxygen species by the cells, as well as the release of cytokines, such as TNF and IL-1 $[67,68]$. Interleukin-1 stimulates the release of lactoferrin from neutrophils. This is important because of the ability to eliminate both the pathogen and the infected cells. Viruses (e.g., Sendai virus, influenza virus, cytomegalovirus, HIV) may contribute to increased production of ROS by phagocytes (murine splenocytes, human neutrophils, monocytes) [69-71]. Also, inhibition of apoptosis resulted in the accumulation of over-reactive neutrophils in tissues that can cause tissular damage, resulting in inflammation (e.g., neutrophils infected with HCMV) [72]. The aim of phagocytes in case of eukaryotic pathogenic virus is to destroy and remove with the use of all available mechanisms. Viral infection causes changes in the functioning of the immune system of the body in which the infection develops. Table 1 summarizes the comparison of the influence of pathogenic eukaryotic and nonpathogenic (phages) viruses on phagocyte functions. Based on the above information, the pathogenic viruses have a different mechanism of action on phagocytic cells of the immune system than bacterial viruses. 
Table 1. The influence of pathogenic and nonpathogenic (phages) viruses on phagocyte functions.

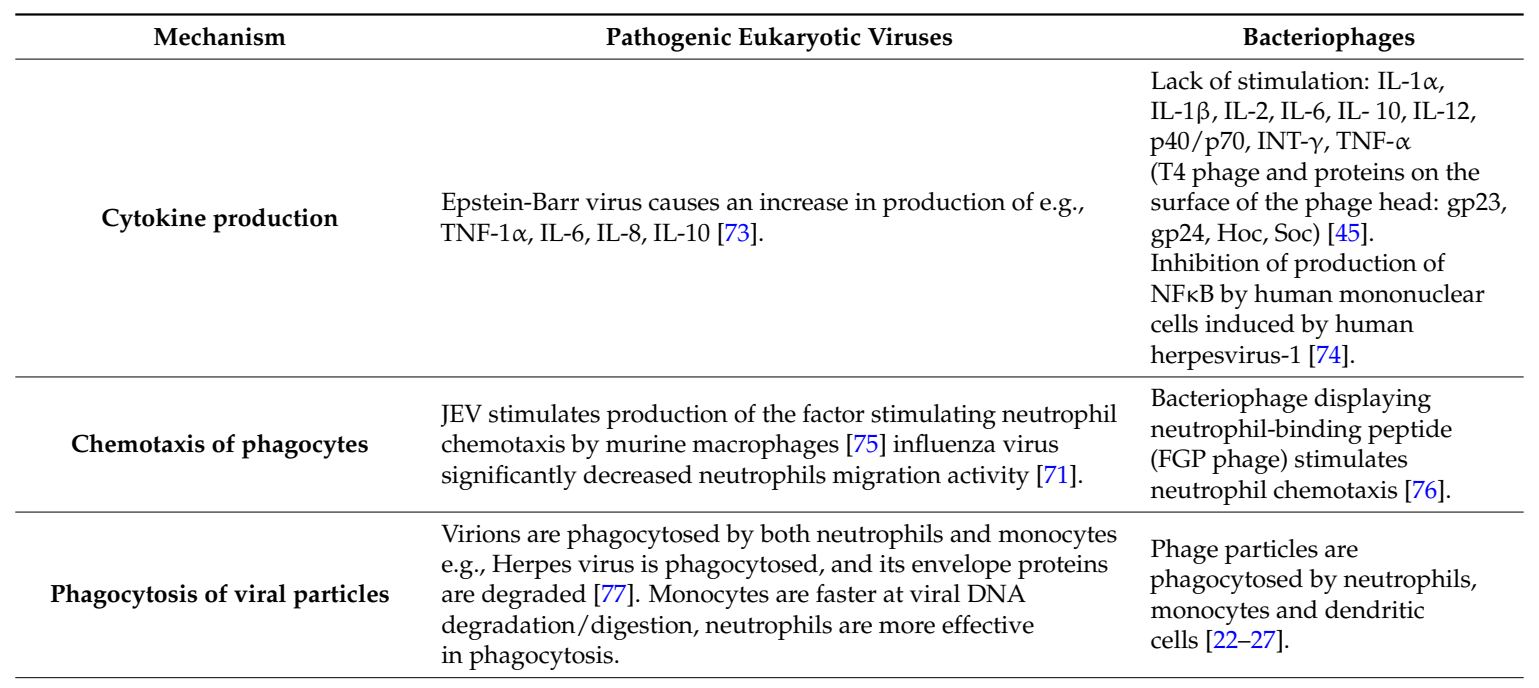

Active Mumps and the influenza viruses, inhibited the process of B. anthracis phagocytosis [78]. EBV reduced phagocytic activity of human monocytes, Influenza virus decreased phagocytosis of bacteria by human neutrophils $[79,80]$ and murine macrophages [81] In HIV-positive patients the process of formation of the phagosome was impaired Coxsackie virus exerted an inhibitory effect on the ability of leukocytes to phagocytose, and it was dependent on the time of leukocytes' exposure to the virus [82] Human neutrophils infected with HCMV increased expression of CD11 receptor (responsible for Influence on phagocytosis adhesion to the surface of vascular endothelial cells, migration, and phagocytosis of the particles opsonized with complement), resulting in increased phagocytosis [72]. Japanese encephalitis virus caused a reduction in phagocytosis of red dye by human neutrophils, there was no weakening of phagocytic activity for monocytes [83]. The Newcastle disease virus inhibited the phagocytosis of particles of red oil by: human neutrophils after stimulation with zymosan by and oxygen consumption after the stimulation of the cells with PMA, the activity of the membrane-bound enzyme NADPH was also decreased [84].

Viral particles are absorbed into the interior of the phagosome, It occurs in macrophages [22] wherein the lysis takes place (e.g., inactivation of influenza virus by human neutrophils) [79].

There was a weakening in phagocytosis of $S$. aureus by patients' neutrophils which showed an initial decrease in the process [33]. and stimulated neutrophils (e.g., phage $\lambda$ ) [85].

Weakening in bactericidal activity of macrophages and neutrophil functions [80,81].

Lack of stimulation; lack of inhibition in vitro [35] and ex vivo [34].

Neither the purified A3/R

phage nor its lysate stimulates neutrophil degranulation [47]. degranulation [86].

Lowered production or lack of stimulation (e.g., T4, F-8, A3/R) [47].

Sendai virus, influenza virus, cytomegalovirus, HIV caused the increased production of ROS by phagocytes (murine splenocytes, human neutrophils, monocytes) [69-71]. Sendai virus inactivated by ultraviolet light. Heat-inactivated virus did not stimulate the production of ROS. Only active viral particles stimulate the synthesis of ROS by phagocytes [70]. Weakened production by neutrophils and monocytes (HIV) [87].

Rotavirus, enter the host cells by using the interaction between the viral protein VP4 and $\alpha \mathrm{V} \beta 3$-integrin on the cell surface [88].

$\beta$-integrin [17].

Delay in apoptosis of human neutrophils infected with HCMV [83]. Acceleration of neutrophil apoptosis in HIV No data. patients) [89].

Influence on apoptosis

TNF, Tumor necrosis factor; NFkB, Nuclear factor кB; JEV, Japanese encephalitis virus; EBV, Epstein-Barr Virus; HIV, Human Immunodeficiency virus; HCMV, Human Cytomegalovirus; PMA, Phorbol 12-myristate 13-acetate. 
Bacteriophages are not pathogenic for human and animals and although that they can interact with phagocytic cells and be adsorbed to the mammalian cells surface receptors, phagocytosed and degraded, they are not potentially threatening. Despite the fact that phages constantly interact with human organisms (they are present in drinking water, air, food, and soil), and they are a natural component of the biosphere, the therapeutic doses of phage particles contained in phage preparations are higher than those of environmental exposure [17]. Figure 1 presents summarized interactions between phages and phagocytes and possible implications for phage application in the therapy.
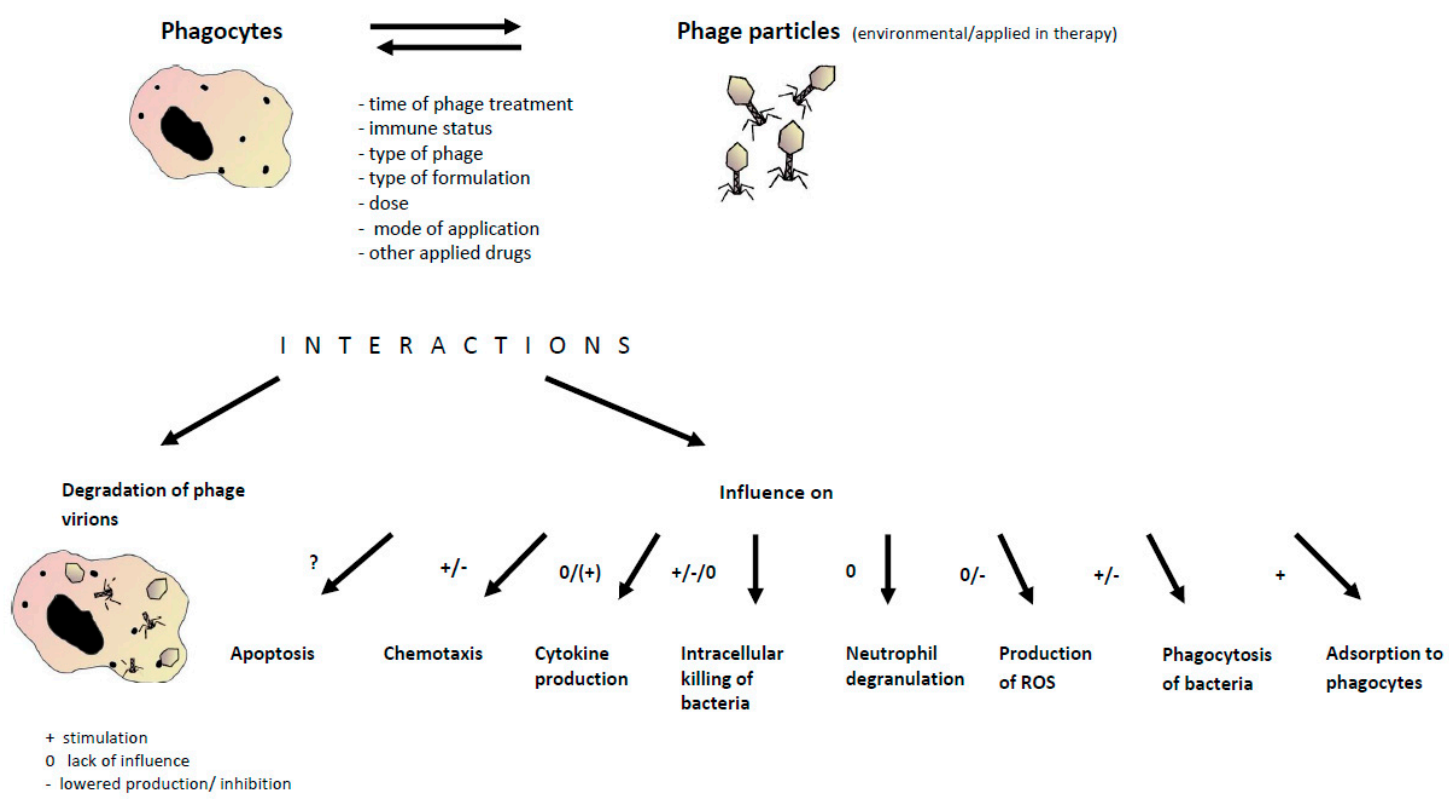

Figure 1. Summary of interactions between phages and phagocytes and possible implications for phage application in therapy. These interactions may be mediated by phages present in our environment and administered during phage therapy, and depend on a variety of factors (e.g., time of phage treatment, etc., as shown). As a result, various phagocyte functions may be affected which can have practical implications for the effectiveness of phage therapy.

The data presented herein indicate that in the response to the phage the immune system does not produce cytokines and ROS and does not cause neutrophil degranulation. It indicates that the phage does not cause an inflammatory response that may be harmful for tissues. What is more, there is a possibility to stimulate the uptake of pathogenic bacteria which may help in controlling the infection not only by their antibacterial activity but as an effect of interactions with phagocytes. Therefore, it is of particular importance that the data presented herein indicated phages not to be toxic, unsafe or to cause harmful side-effects on immune cells in patients treated with phages. Because of phage variety more studies are needed, and especially those used in phage therapy should be evaluated.

\section{Conclusions}

Studies involving interactions with phages of immune cells are essential for the understanding of the role of phages in nature and rational use of phage therapy [20]. It is necessary to assess whether the phages contained in the formulations applied to the patients can stimulate the immune system to eliminate pathogenic bacteria, or decrease the antimicrobial activity of the immune system. The impact of phages on cells of the immune system is an interesting area for future research. Knowledge about the interaction between phages and mammalian cells, in particular phagocytes, is limited so far. Interactions between phages and mammalian cells of the immune system are based primarily on the immunogenic properties of phages (the production of specific antibodies by phage antigens) and immunomodulatory effects on the immune system of mammals (the function of phagocytes-such as 
phagocytosis, production of reactive oxygen species or proliferation of T lymphocytes). Studies on the effects of phages on immune cells may provide important information on the safety of phage therapy. As has been shown, phage-phagocyte interactions differ from interactions of phagocytes with pathogenic viruses.

Most studies have been conducted in vitro or in animal models, and more detailed studies especially in humans are needed. Moreover, there are still processes for which the influence of phages has not been described yet (e.g., apoptosis).

We believe that the recent progress in knowledge concerning the influence of phages on phagocytes and their interactions will significantly expand our knowledge about the role of phages and improve phages' therapeutic applications.

Acknowledgments: This work was supported by Wrocław Center for Biotechnology under the Leading National Research Center (KNOW) program for the years 2014-2018 granted by the Minister of Science and Higher Education.

Author Contributions: E.J.-M. drafted the main part of the manuscript, and prepared Table 1 and Figure 1. B.W.-D., R.M. and B.O., M.Ł.-S. and prepared parts of the manuscript, N.Ł. took part in preparation of Figure 1 and the revised version of the manuscript, A.G. gave support and conceptual advice at all stages of manuscript preparation. All authors revised the manuscript.

Conflicts of Interest: The authors declare that there is no conflict of interests regarding the publication of this paper.

\section{References}

1. Hazenbos, W.L.W.; Brown, E.J. Phagocytosis: Receptors and biology. In Phagocytosis of Bacteria and Bacterial Pathogenicity; Advances in Molecular and Cellular Microbiology, (No. 12); Ernst, J.D., Stendahl, O., Eds.; Cambridge University Press: Cambridge, UK, 2006; ISBN-13 9780511242977.

2. Metchnikoff, E. On the present state of the question of immunity in infectious diseases. Proceedings of the Nobel Lecture, Stockholm, 11 December 1908. reprinted in Scand. J. Immunol. 1989, 30, 383-398.

3. Hampton, M.B.; Kettle, A.J.; Winterbourn, C. Inside the neutrophil phagosome: Oxidants, myeloperoxidase, and bacterial killing. Blood 1998, 92, 3007-3017. [PubMed]

4. Labro, M.T. Interference of antibacterial agents with phagocyte functions: Immunomodulation or "immune-fairy tales"? Clin. Microbiol. Rev. 2000, 13, 615-650. [CrossRef] [PubMed]

5. Peripheral Blood: Reference Ranges. Adapted from University of Washington Medical Center. Prepared by Patients Against Lymphoma. Available online: http://www.lymphomation.org/peripheral-blood-ref.pdf (accessed on 20 May 2017).

6. Kobayashi, S.D.; Voyich, J.M.; Burlak, C.; DeLeo, F. Neutrophils in the innate immune response. Arch. Immunol. Ther. Exp. 2005, 53, 505-517.

7. Andreesen, R.; Kreutz, M. Differentiation of human monocytes in vitro: A model of macrophage ontogeny. In Cell Culture in Pharmaceutical Research; Ernst Schering Research Foundation Workshop; Springer: Berlin/Heidelberg, Germany, 1994; Volume 11, pp. 9-27.

8. Murray, P.R.; Rosenthal, K.S.; Pfaller, M.A. Mikrobiologia; Przondo-Mordarska, A., Martirosian, G., Szkaradkiewicz, A., Eds.; Elsevier Urban \& Partner: Wrocław, Poland, 2011.

9. Johansson, A.A.J.; Jesaitis, H.; Lundquist, K.E.; Magnusson, C.; Sjolin, A.; Karlsson, A.; Dahlgren, C. Different subcellular localization of cytochrome $b$ and the dormant NADPH-oxidase in neutrophils and macrophages: Effect of the production of reactive oxygen species during phagocytosis. Cell Immunol. 1995, 161, 61-71. [CrossRef] [PubMed]

10. Liao, H.F.; Yang, Y.C.; Chen, Y.Y.; Hsu, M.L.; Shieh, H.R.; Chen, Y.J. Macrophages derived from bone marrow modulate differentiation of myeloid dendritic cells. Cell. Mol. Life Sci. 2007, 64, 104-111. [CrossRef] [PubMed]

11. Underhill, D.M.; Goodridge, H.S. Information processing during phagocytosis. Immunology 2012, 12, 492-502. [CrossRef] [PubMed]

12. Hendrix, R.W.; Smith, M.C.M.; Burns, R.N.; Ford, M.E.; Hatfull, G.F. Evolutionary relationships among diverse bacteriophages and prophages: All the world's a phage. Proc. Natl. Acad. Sci. USA 1999, 96, 2192-2197. [CrossRef] [PubMed]

13. Hendrix, R.W. Bacteriophages: Evolution of the majority. Theor. Popul. Biol. 2002, 61, 471-480. [CrossRef] 
14. Abedon, S.T.; Thomas-Abedon, C.; Thomas, A.; Mazure, H. Bacteriophage prehistory: Is or is not Hankin, 1896, a phage reference? Bacteriophage 2011, 1, 174-178. [CrossRef] [PubMed]

15. Reyes, A.; Semenkovich, N.P.; Whiteson, K.; Rohwer, F.; Gordon, J.I. Going viral: Next-generation sequencing applied to phage populations in the human gut. Nat. Rev. Microbiol. 2012, 10, 607-617. [CrossRef] [PubMed]

16. Międzybrodzki, R.; Borysowski, J.; Weber-Dąbrowska, B.; Fortuna, W.; Letkiewicz, S.; Szufnarowski, K.; Pawełczyk, Z.; Rogóż, P.; Kłak, M.; Wojtasik, E.; et al. Clinical aspects of phage therapy. Adv. Virus Res. 2012, 83, 73-121. [PubMed]

17. Dąbrowska, K.; Opolski, A.; Wietrzyk, J.; Świtala-Jeleń, K.; Boratyński, J.; Nasulewicz, A.; Lipińska, L.; Chybicka, A.; Kujawa, M.; Zabel, M.; et al. Antitumor activity of bacteriophages in murine experimental cancer models caused possibly by inhibition of beta3 integrin signaling pathway. Acta Virol. 2004, 48, 241-248.

18. NIAID's Antibacterial Resistance Program: Current Status and Future Directions (2014). Available online: http://www.niaid.nih.gov/topics/antimicrobialresistance/documents/arstrategicplan2014.pdf (accessed on 23 September 2015).

19. Jassim, A.A.A.; Limoges, R.G. Natural solution to antibiotic resistance: Bacteriophages "The Living Drugs". World J. Microbiol. Biotechnol. 2014, 30, 2153-2170. [CrossRef] [PubMed]

20. Górski, A.; Międzybrodzki, R.; Borysowski, J.; Dąbrowska, K.; Wierzbicki, P.; Ohams, M.; Korczak-Kowalska, G.; Olszowska, N.; Łusiak-Szelachowska, M.; Kłak, M.; et al. Phage as a modulator of immune responses: Practical implications for phage therapy. Adv. Virus Res. 2012, 83, 41-71. [PubMed]

21. Kurzepa, A.; Dabrowska, K.; Skaradziński, G.; Górski, A. Bacteriophage interactions with phagocytes and their potential significance in experimental therapy. Clin. Exp. Med. 2009, 9, 93-100. [CrossRef] [PubMed]

22. Aronow, R.; Danon, D.; Shahar, A.; Aronson, M. Electron microscopy of in vitro endocytosis of T2 phage by cells from rabbit peritoneal exudate. J. Exp. Med. 1964, 120, 943-954. [CrossRef] [PubMed]

23. Wenger, S.L.; Turner, J.H.; Petricciani, J.C. The cytogenetic, proliferative and viability effects of four bacteriophages on human lymphocytes. In Vitro 1978, 14, 543-549. [CrossRef] [PubMed]

24. Ivanenkov, V.; Felici, F.; Menon, A.G. Uptake and intracellular fate of phage display vectors in mammalian cells. Biochim. Biophys. 1999, 1448, 450-462. [CrossRef]

25. Barfoot, R.; Denham, S.; Gyure, L.A.; Hall, J.G.; Hobbs, S.M.; Jackson, L.E.; Robertson, D. Some properties of dendritic macrophages from peripheral lymph. Immunology 1989, 68, 233-239. [PubMed]

26. Kaźmierczak, Z.; Piotrowicz, A.; Owczarek, B.; Hodyra, K.; Miernikiewicz, P.; Lecion, D.; Harhala, M.; Górski, A.; Dabrowska, K. Molecular imaging of T4 phage in mammalian tissues and cells. Bacteriophage 2014, 4, e28364. [CrossRef] [PubMed]

27. Hodyra-Stefaniak, K.; Miernikiewicz, P.; Drapała, J.; Drab, M.; Jończyk-Matysiak, E.; Lecion, D.; Kaźmierczak, Z.; Beta, W.; Majewska, J.; Bubak, B.; et al. Mammalian host-versus-phage immune response determines phage fate in vivo. Sci. Rep. 2015, 5, 14802. [CrossRef] [PubMed]

28. D'Herelle, F. Bacteriophage: Its Role in Immunity; Williams \& Wilkins Company: Baltimore, MD, USA, 1922.

29. Nelson, A.R. The effect of bacteriophage upon the phenomena of leukocytosis and phagocytosis. J. Immunol. 1928, 15, 43-64.

30. Młynarczyk, G.; Garliński, P.; Młynarczyk, A.; Zabuska, K.; Sawicka-Grzelak, A.; Machowska, G.; Osowiecki, H.; Roszkowski, W. Bacteriophage conversion as a factor modifying the intensity of phagocytosis of Staphylococcus aureus by human leukocytes. Med. Doświadczalna Mikrobiol. 1989, 41, 86-91.

31. Secor, P.R.; Michaels, L.A.; Smigiel, K.S.; Rohani, M.G.; Jennings, L.K.; Hisert, K.B.; Arrigoni, A.; Braun, K.R.; Birkland, T.P.; Lai, Y.; et al. Filamentous bacteriophage produced by Pseudomonas aeruginosa alters the inflammatory response and promotes noninvasive infection in vivo. Infect. Immunol. 2017, 85, e0648-16. [CrossRef] [PubMed]

32. Smith, G.H. Bacteriophage and phagocytosis. I Effect on resistant and dead bacteria. J. Immunol. 1928, $15,125-140$.

33. Weber-Dąbrowska, B.; Zimecki, M.; Mulczyk, M.; Górski, A. Effect of phage therapy on the turnover and function of peripheral neutrophils. FEMS Immunol. Med. Microb. 2002, 34, 135-138. [CrossRef]

34. Jończyk-Matysiak, E.; Łusiak-Szelachowska, M.; Kłak, M.; Bubak, B.; Międzybrodzki, R.; Weber-Dabrowska, B.; Żaczek, M.; Fortuna, W.; Rogóż, P.; Letkiewicz, S.; et al. The effect of bacteriophage preparations on intracellular killing of bacteria by phagocytes. J. Immunol. Res. 2015, 2015, 482863. [CrossRef] [PubMed] 
35. Kurzępa-Skaradzińska, A.; Łusiak-Szelachowska, M.; Skaradziński, G.; Jończyk-Matysiak, E.; Weber-Dąbrowska, B.; Żaczek, M.; Maj, T.; Sławek, A.; Rymowicz, W.; Kłak, M.; et al. Influence of bacteriophage preparations on intracellular killing of bacteria by human phagocytes in vitro. Viral Immunol. 2013, 26, 150-162. [CrossRef] [PubMed]

36. Chhibber, S.; Kaur, T.; Kaur, S. Co-therapy using lytic bacteriophage and linezolid: Effective treatment in eliminating methicillin resistant Staphylococcus aureus (MRSA) from diabetic foot infections. PLoS ONE 2013, 8, e56022. [CrossRef] [PubMed]

37. Tiwari, B.R.; Kim, S.; Rahman, M.; Kim, J. Antibacterial efficacy of lytic Pseudomonas bacteriophage in normal and neutropenic mice models. J. Microbiol. 2011, 49, 994-999. [CrossRef] [PubMed]

38. Briones, E.; Colino, C.I.; Lanao, J.M. Delivery systems to increase the selectivity of antibiotics in phagocytic cells. J. Control. Release 2008, 125, 210-227. [CrossRef] [PubMed]

39. Broxmeyer, L.; Sosnowska, D.; Miltner, E.; Chacćon, O.; Wagner, D.; McGarvey, J.; Bareltta, R.G.; Bermudez, L. Killing of Mycobacterium avium and Mycobacterium tuberculosis by a mycobacteriophage delivered by a nonvirulent mycobacterium: A model for phage therapy of intracellular bacterial pathogens. J. Infect. Dis. 2002, 186, 1155-1160. [CrossRef] [PubMed]

40. Capparelli, R.; Parlato, M.; Borriello, G.; Salvatore, P.; Iannelli, D. Experimental phage therapy against Staphylococcus aureus in mice. Antimicrob. Agents Chemiother. 2007, 51, 2765-2773. [CrossRef] [PubMed]

41. Kaur, S.; Harjai, K.; Chhibber, S. Bacteriophage-aided intracellular killing of engulfed methicillin-resistant Staphylococcus aureus (MRSA) by murine macrophages. Appl. Microbiol. Biotechnol. 2014, 98, 4653-4661. [CrossRef] [PubMed]

42. Baughn, R.; Bonventre, P.F. Phagocytosis and intracellular killing of Staphylococcus aureus by normal mouse peritoneal macrophages. Infect. Immun. 1975, 12, 346-352. [PubMed]

43. Przerwa, A.; Zimecki, M.; Świtała-Jeleń, K.; Dąbrowsk, K.; Krawczyk, E.; Łuczak, M.; Weber-Dabbrowska, B.; Syper, D.; Międzybrodzki, R.; Górski, A. Effects of bacteriophages on free radical production and phagocytic functions. Med. Microbiol. Immunol. 2006, 195, 143-150. [CrossRef] [PubMed]

44. Międzybrodzki, R.; Świtala-Jeleń, K.; Fortuna, W.; Weber-Dabrowska, B.; Przerwa, A.; Łusiak-Szelachowska, M.; Dąbrowska, K.; Kurzępa, A.; Boratyński, J.; Syper, D.; et al. Bacteriophage preparation inhibition of reactive oxygen species generation by endotoxin-stimulated polymorphonuclear leukocytes. Virus Res. 2008, 131, 233-242.

45. Miernikiewicz, P.; Dabrowska, K.; Piotrowicz, A.; Owczarek, B.; Wojas-Turek, J.; Kicielińska, J.; Rossowska, J.; Pajtasz-Piasecka, E.; Hodyra, K.; Macegoniuk, K.; et al. Cytokine profiles in mice and in human blood treated with phage proteins. PLOS ONE 2013, 8, e71036.

46. Borysowski, J.; Wierzbicki, P.; Kłosowska, D.; Korczak-Kowalska, G.; Weber-Dąbrowska, B.; Górski, A. The effects of T4 and A3/R phage preparations on whole-blood monocyte and neutrophil respiratory burst. Viral Immunol. 2010, 23, 541-544. [CrossRef] [PubMed]

47. Borysowski, J.; Międzybrodzki, R.; Wierzbicki, P.; Kłosowska, D.; Korczak-Kowalska, G.; Weber-Dabrowska, B.; Górski, A. A3R phages and Staphylococcus aureus lysate do not induce neutrophil degranulation. Viruses 2017, 9, 36. [CrossRef] [PubMed]

48. Górski, A.; Międzybrodzki, R.; Weber-Dabrowska, B.; Fortuna, W.; Letkiewicz, S.; Rogóż, P.; Jończyk-Matysiak, E.; Dabrowska, K.; Majewska, J.; Borysowski, J. Phage Therapy: Combating Infections with Potential for Evolving from Merely a Treatment for Complications to Targeting Diseases. Front. Microbiol. 2016, 7, 1515. [CrossRef] [PubMed]

49. Bocian, K.; Borysowski, J.; Zarzycki, M.; Pacek, M.; Weber-Dąbrowska, B.; Machcińska, M.; Korczak-Kowalska, G.; Górski, A. The effects of T4 and A3/R bacteriophages on differentiation of human myeloid dendritic cells. Front. Microbiol. 2016, 7, 1267. [CrossRef] [PubMed]

50. Bocian, K.; Borysowski, J.; Zarzycki, M.; Wierzbicki, P.; Kłosowska, D.; Weber-Dabrowska, B.; Korczak-Kowalska, G.; Górski, A. LPS-activated monocytes are unresponsive to T4 phage and T4-generated Escherichia coli lysate. Front. Microbiol. 2016, 7, 1356. [CrossRef] [PubMed]

51. Ann, T.W.; Kim, S.J.; Lee, Y.D.; Park, J.H.; Chang, H.I. The immune-enhancing effect of the Cronobacter sakazakii ES2 phage results in the activation of nuclear factor- $\mathrm{kB}$ and dendritic cell maturation via the activation of IL-12p40 in the mouse bone marrow. Immunol. Lett. 2014, 157, 1-8. [CrossRef] [PubMed] 
52. Miernikiewicz, P.; Kłopot, A.; Soluch, R.; Szkuta, P.; Kęska, W.; Hodyra-Stefaniak, K.; Konopka, A.; Nowak, M.; Lecion, D.; Kaźmierczak, Z.; et al. T4 phage tail adhesin gp12 counteracts LPS-induced inflammation in vivo. Front. Microbiol. 2016, 7, 1112. [CrossRef] [PubMed]

53. Anany, H.; Chen, W.; Pelton, R.; Griffiths, M.W. Biocontrol of Listeria monocytogenes and Escherichia coli O157:H7 in meat by using phages immobilized on modified cellulose membranes. Appl. Environ. Microbiol. 2011, 6379-6387. [CrossRef] [PubMed]

54. Dąbrowska, K.; Zembala, M.; Boratyński, J.; Świtała-Jeleń, K.; Wietrzyk, J.; Opolski, A.; Szczaurska, K.; Kujawa, M.; Godlewska, J.; Górski, A. Hoc protein regulates the biological effects of T4 phage in mammals. Arch. Microbiol. 2007, 187, 489-498. [CrossRef] [PubMed]

55. Kruger, A.P.; Ritter, R.C.; Smith, P. The electrical charge of bacteriophage. J. Exp. Med. 1929, 50, 739-746. [CrossRef]

56. Burnet, F.M.; Mckie, M. The electrical behaviour of bacteriophages. Aust. J. Exp. Biol. Med. Sci. 1930, 7, 199-209. [CrossRef]

57. Zemb, O.; Manefield, M.; Thomas, F.; Jacquet, S. Phage adsorption to bacteria in the light of the electrostatics: a case study using E. coli, T2 and flow cytometry. J. Virol. Methods 2013, 189, 283-289. [CrossRef] [PubMed]

58. Getts, D.R.; Terry, R.L.; Getts, M.T.; Deffrasnes, C.; Müller, M.; van Vreden, C.; Ashhurst, T.M.; Chami, B.; McCarthy, D.; Wu, H.; et al. Therapeutic inflammatory monocyte modulation using immune-modifying microparticles. Sci. Transl. Med. 2014, 6, 219ra7. [CrossRef] [PubMed]

59. Zimecki, M.; Weber-Dabbrowska, B.; Łusiak-Szelachowska, M.; Mulczyk, M.; Boratyński, J.; Poźniak, G.; Syper, D.; Górski, A. Bacteriophages provide regulatory signals in mitogen-induced murine splenocyte proliferation. Cell. Mol. Biol. Lett. 2003, 8, 699-711. [PubMed]

60. Stapels, D.C.A.; Ramyar, K.X.; Bischoff, M.; von Köckritz-Blickwede, M.; Milder, F.J.; Ruyken, M.; Eisenbeis, J.; McWhorter, W.J.; Herrmann, M.; van Kessel, K.P.; et al. Staphylococcus aureus secretes a unique class of neutrophil serine protease inhibitors. Proc. Natl. Acad. Sci. USA 2014, 111, 13187-13192. [CrossRef] [PubMed]

61. Międzybrodzki, R.; Fortuna, W.; Weber-Dabrowska, B.; Górski, A. A retrospective analysis of changes in inflammatory markers in patients treated with bacterial viruses. Clin. Exp. Med. 2009, 9, 303-312. [CrossRef] [PubMed]

62. Jończyk-Matysiak, E.; Kłak, M.; Łusiak-Szelachowska, M.; Bubak, B.; Międzybrodzki, R.; Weber-Dąbrowska, B.; Żaczek, M.; Górski, A. The effect of bacteriophage preparations on bone marrow functions and the level of inflammatory markers in blood of patients treated with phage preparations. In Proceedings of the 21st Biennial Evergreen International Phage Meeting, Evergreen, Washington, DC, USA, 2-8 August 2015.

63. Delves, P.J.; Martin, S.J.; Burton, D.R.; Roitt, I.M. Roitt's Essential Immunology, Includes Desktop Edition, 12th ed.; Wiley-Blackwell: Hoboken, NJ, USA, 2011; ISBN-13 978-1405196833.

64. Rosen, G.M.; Pou, S.; Ramos, C.L.; Cohen, M.S.; Britigan, B.E. Free radicals and phagocytic cells. FASEB J. 1995, 9, 200-209. [PubMed]

65. Selsted, M.E.; Harwig, S.L. Purification, primary structure, and antimicrobial activities of a guinea pig neutrophil defensin. Infect. Immun. 1987, 55, 2281-2286. [PubMed]

66. Zerial, A.; Skerlavaj, B.; Gennaro, R.; Romeo, D. Inactivation of herpes simplex virus by protein components of bovine neutrophil granules. Antivir. Res. 1987, 7, 341-352. [CrossRef]

67. Klempner, M.S.; Dinarello, C.A.; Gallis, J.I. Human leukocytic pyrogen induces release of specific granule contents from human neutrophils. J. Clin. Investig. 1978, 61, 1330-1336. [CrossRef] [PubMed]

68. Schwarz, K.B. Oxidative stress during viral infection: A review. Free Radic. Biol Med. 1996, 21, 641-649. [CrossRef] [PubMed]

69. Suzuki, S.; Kimura, T.; Ikuta, K. Superoxide generation and human cytomegalovirus infection. Nihon Rinsho 1998, 56, 75-78. [PubMed]

70. Peterhans, E. Sendai virus stimulates chemiluminescence in mouse spleen cells. Biochem. Biophys. Res. Commun. 1979, 91, 383-392. [CrossRef]

71. Debets-Ossenkopp, Y.; Mills, E.L.; van Dajk, W.C.; Verbrugh, H.A.; Verhoef, J. Effect of influenza virus on phagocytic cells. Eur. J. Clin. Microbiol. 1982, 1, 171-177. [CrossRef] [PubMed]

72. Skarman, P.J.; Rahbar, A.; Xie, X.; Söderberg-Nauclér, C. Induction of polymorphonuclear leucocyte response by human cytomegalovirus. Microbes Infect. 2006, 8, 1592-1601. [CrossRef] [PubMed] 
73. Savard, M.; Bélanger, C.; Tardif, M.; Gourde, P.; Flamand, L.; Gosselin, J. Infection of primary human monocytes by Epstein-Barr virus. J. Virol. 2000, 74, 2612-2619. [CrossRef] [PubMed]

74. Gorczyca, W.A.; Mitkiewicz, M.; Siednienko, J.; Kurowska, E.; Piasecki, E.; Weber-Dabrowska, B.; Górski, A. Bacteriophages decrease activity of NFKB induced in human mononuclear cells by human herpesvirus-1. In Proceedings of the 13th International Congress of Immunology, Rio de Janeiro, Brasil, 21-25 August 2007.

75. Khanna, N.; Agnihotri, M.; Mathur, A.; Chaturvedi, U.C. Neutrophil chemotactic factor produced by Japanese encephalitis virus stimulated macrophages. Clin. Exp. Immunol. 1991, 86, 299-303. [CrossRef] [PubMed]

76. Jaye, D.L.; Edens, H.A.; Mazzucchelli, L.; Parkos, C.A. Novel G protein-coupled responses in leukocytes elicited by a chemotactic bacteriophage displaying a cell type-selective binding peptide. J. Immunol. 2001, 166, 7250-7259. [CrossRef] [PubMed]

77. Van Strijp, J.A.; Miltenburg, L.A.; van der Tol, M.E.; Van Kessel, K.P.; Fluit, A.C.; Verhoef, J. Degradation of herpes simplex virions by human polymorphonuclear leukocytes and monocytes. J. Gen. Virol. 1990, 71, 1205-1209. [CrossRef] [PubMed]

78. Merchant, D.J.; Morgan, H.R. Inhibition of the phagocytic action of leucocytes by mumps and influenza viruses. Proc. Soc. Exp. Biol. Med. 1950, 74, 651-653. [CrossRef] [PubMed]

79. Yamamoto, K.; Suzuki, K.; Suzuki, K.; Mizuno, S. Phagocytosis and ingestion of influenza virus by human polymorphonuclear leucocytes in vitro: Electromicroscopy studies. J. Med. Microbiol. 1989, 28, 191-198. [CrossRef] [PubMed]

80. Pang, G.; Clancy, R.; Gong, M.; Ortega, M.; Ren, Z.G.; Reeves, G. Influenza virus inhibits lysozyme secretion by sputum neutrophils in subjects with chronic bronchial sepsis. Am. J. Respir. Crit. Care Med. 2000, 161, 718-722. [CrossRef] [PubMed]

81. Warr, G.A.; Jakab, G.J.; Chan, T.W.; Tsan, M.F. Effects of viral pneumonia on lung macrophage lysosomal enzymes. Infect. Immun. 1979, 24, 577-579. [PubMed]

82. Kańtoch, M.; Dubowska-Inglot, A. Inhibition of phagocytic activity of leukocytes by Coxsackie virus. I: The influence of the viral concentration and temperature on the inhibition of phagocytosis. Pathol. Microbiol. 1960, 23, 83-94.

83. Chaturvedi, U.C.; Mathur, A.; Tandon, P.; Natu, S.M.; Ray-Vanishi, S.; Tandon, H.O. Variable effect on peripheral blood leucocytes during JE virus infection of man. Clin. Exp. Immunol. 1979, 38, 492-498. [PubMed]

84. Faden, H.; Humbert, J.; Lee, J.; Sutyla, P.; Ogra, P.L. The in vitro effects of Newcastle disease virus on the metabolic and antibacterial functions of human neutrophils. Blood 1981, 58, 221-227. [PubMed]

85. Ferrini, U.; Mileo, M.M.; Nista, A.; Mattei, E.; Orofino, A. Polymorphonuclear leucocyte stimulation measured by phage inactivation. Int. Arch. Allergy Appl. Immunol. 1989, 90, 207-212. [CrossRef] [PubMed]

86. Jaovisidha, P.; Peeples, M.E.; Brees, A.A.; Carpenter, L.R.; Moy, J.N. Respiratory syncytial virus stimulates neutrophil degranulation and chemokine release. J. Immunol. 1999, 163, 2816-2820. [PubMed]

87. Michailidis, C.; Giannopoulos, G.; Vigklis, V.; Armenis, K.; Tsakris, A.; Gargalianos, P. Impaired phagocytosis among patients infected by the human immunodeficiency virus: Implication for a role of highly active anti-retroviral therapy. Clin. Exp. Immunol. 2012, 167, 499-504. [CrossRef] [PubMed]

88. Arias, C.F.; Isa, P.; Guerrero, C.A.; Méndez, E.; Zárate, S.; López, T.; Espinosa, R.; Romero, P.; López, S. Molecular biology of rotavirus cell entry. Arch. Med. Res. 2002, 33, 356-361. [CrossRef]

89. Pitrak, D.; Tsai, H.; Mullane, K.; Sutton, S.; Stevens, P. Accelerated neutrophil apoptosis in the acquired immunodeficiency syndrome. J. Clin. Investig. 1996, 98, 2714-2719. [CrossRef] [PubMed]

(C) 2017 by the authors. Licensee MDPI, Basel, Switzerland. This article is an open access article distributed under the terms and conditions of the Creative Commons Attribution (CC BY) license (http://creativecommons.org/licenses/by/4.0/). 